\title{
THE INFLUENCE OF EXPERIENTIAL LEARNING WITH PHYSICAL MOVEMENT ACTIVITIES ON SOCIAL STATUS OF INTEGRATED PUPILS WITH BEHAVIOURAL DISORDERS

\author{
Zuzana Pintérová, Janka Peráčková
} \\ Department of Sport Educology and Sport Humanities, Faculty of Physical Education and Sport, Comenius University in Bratislava
}

\begin{abstract}
Summary: The aim of the study was to broaden the knowledge about experiential education comprising of physical movement and sport activities as a part of the educational process and to verify the potential influence of experiential education on the changes in the field of social relationships in selected integrated classes with pupils suffering from behavioural disorders. To meet this goal, we used a standardized psycho-diagnostic method, a socio-metric rating questionnaire, by which means we proved the positive influence of the experiential education programme connected to movement on the overall improvement of the social structure of a class with pupils with behavioural disorders and their status in the class's hierarchy. We formulated recommendations for the practical field based on this fact.
\end{abstract}

Key words: physical movement activity, experiential learning, social status, integrated pupils, behavioural disorders

DOI 10.1515/afepuc-2015-0010

(C) Acta Facultatis Educationis Physicae Universitatis Comenianae 


\section{Introduction}

Verešová (2014) defines experience as every mental phenomenon a person goes through. It is always exclusively internal, subjective and accompanied by emotions. Experience becomes the source of personal expertise; it accumulates throughout the whole life and creates each person's unique mental wealth. According to Hanuš and Chytilová (2008), activities intended for eliciting an experience, whether based on competitiveness, happiness or some other emotional aspect, have one thing in common: A person has the feeling of discovering something and experiences give us a creative feeling of getting into a new, different reality. Experiences contribute to higher quality of performance and get us into a state of consciousness we never even dreamed about. The main constituent of experiential education (Pelánek 2008) should be the pupil's own activity, by means of which he will acquire his experiences. The more he puts his strength and performance into an activity, the more valuable, intense and exploitable the experience will be for education and practice.

A significant factor for diagnosing relationships in class is the class climate. It is a social-psychological term that recently became very popular (Čapek 2010). Class climate is a set of all external and internal conditions mutually effecting pupils and teachers and influencing their behaviour (Vykopalová 1992).

Behavioural disorders, the occurrence of which is nowadays not exceptional (Vágnerová 2005), are perceived as certain deviations in the field of socialization, in which situations occur when an individual is not capable of respecting norms and regulations of behaviour on a level adequate to his age, emotional maturity, and intellectual abilities.

Vágnerová (2002), Škoda and Fischer (2008) present factors that increase the likelihood of formation and development of behavioural disorders:

1. Biological factors - sex and age factor.

2. Psychological factors - the need to meet the needs of safety, security, solidarity and love. Unacceptable behaviour can become the object of self-reflection and self-realization.

3. Social factors - family and familial environment, peers.

Martínek (2009) puts these symptoms among the most frequent behavioural disorders of children and teenagers in connection to school attendance:

- Non-aggressive - ADHD (Attention Deficit Hyperactivity Disorder), chronic lying and cheating, truancy, run away from home, and rambling.

- Aggressive - theft, vandalism, bullying. 
According to Oravcová (2004), increasing the resistance of children and teenagers towards behavioural disorders, or rather social-pathological signs, requires the realizers' systemic and coordinated preparation of preventive activities in schools and educational facilities. The society-wide system of preventing behavioural disorders anticipates coordinated collaboration of all components involved with this phenomenon.

\section{Aim}

The aim of this study was to broaden the knowledge about experiential education comprising of physical movement and sport activities as a part of the educational process and to verify the potential influence of experiential education on the changes in the field of social relationships in selected integrated classes with pupils suffering from behavioural disorders.

\section{Methods}

The research was realized at an ecclesiastical elementary school in Bratislava. We utilized the experiential education comprised of physical movement activities programme during the span of seven months of a school year (from November 2012 until the end of May 2013). We applied particular constituents of experiential education in physical education classes two times a week, in the preparatory, main and final part of a lesson. We also used experiential learning within amateur sports clubs and excursions that take place outside of classes. For example, we realized the paddling and touristic course, ski and snowboard training, cycle-touristic course or trips to school in nature. The total number of lessons for the experiment was 41, and various experiential and cooperative activities, didactic games, and heuristic methods, etc. were a part of them.

The research sample consisted of 54 pupils from the sixth and the seventh grade of elementary school from Bratislava. Fifteen pupils out of the total number of pupils from integrated classes (11 boys and 4 girls) were diagnosed with a certain specific behavioural disorders.

\section{Table 1}

Diagnoses of selected pupils sample with behaviour problem

\begin{tabular}{|l|l|l|}
\hline $\begin{array}{l}\text { Integrated } \\
\text { class }\end{array}$ & $\begin{array}{l}\text { Sex of the } \\
\text { integrated pupils }\end{array}$ & $\begin{array}{l}\text { Diagnosed behavioural disorder; } \\
\text { displays of behavioural disorder }\end{array}$ \\
\hline 6.A & boy & ADHD, self-harming, Asperger syndrome, bullying aggressor \\
\hline 6.A & girl & ADHD \\
\hline 6.B & boy & ADHD, dyslexia, delinquency \\
\hline 6.B & girl & dyslexia, frequent thefts \\
\hline 7.A & boy & ADHD, dysgraphia, Asperger syndrome, truancy and lying \\
\hline 7.A & girl & ADHD, mental anorexia and bulimia \\
\hline
\end{tabular}


We created own specific experiential education activities and games, based on previous research works and experiences from praxis. Inspirational basis for the creation of physical movement activities were some specific activities recommended by Pánisová, Peráčková (2012). We assumed that the differences of the influence, popularity and inclination index values between intact and integrated pupils would be significant.

\section{The structure of experiment}

$$
\mathrm{K} / \mathrm{ES}_{6 . \mathrm{A}, 6 . \mathrm{B}, 7 . \mathrm{A}}(\mathrm{SORAD})_{\mathrm{t} 1} \longrightarrow \mathrm{KE} \text { (experiential learning) } \longrightarrow \mathrm{ES} \text { 6.A, 6.B, 7.A }(\mathrm{SORAD})_{\mathrm{t} 2}
$$

For completion of tasks and verification of our hypothesis, we chose the sociometric-rating questionnaire (SORAD). It is a special sociometric procedure developed for psychosocial diagnostics of school classes. It enables to look into the detailed emotional climate of a class; we can observe the current division of social power in class, interaction of subgroups and also discover psychosocial diagnostics of single pupils and, last but not least, their relationships to their classmates. SORAD offers individual diagnostic information about all pupils (Gajdošová 2000).

The process of pupil assessment by SORAD has several phases:

1. The pupils have to assess and evaluate all their classmates, excluding themselves, on a five level scale based on their individual influence in class (e.g. if the particular pupil is a leader, or a marginal member).

2. The pupils have a similar task, with the difference that they have to assess and evaluate all their classmates, excluding themselves, on a scale from one to five points, according to the popularity and liking in class.

In the first two tasks, the pupils have to assess on the ground of this five level scale:

1 very influential/likeable

2 quite influential/likeable

3 nor influential/likeable, nor not influential/unlikeable

4 rather not influential/unlikable

5 not influential/unlikable

The evaluation is realized based on these indexes:

1. Influence index - points out the social position of the pupil in class.

2. Popularity index - points out the emotional position of the pupil in class.

3. Inclination index - the indicator of subjective adaptation.

We applied mathematical-statistical procedures for a complex processing of the results of the research work. We used the Mann - Whitney test for the comparison of two independent samples (the control sample with standard teaching and learning, and an 
identical experimental sample with the physical movement program with experiential teaching and learning) and processed the results into tables.

\section{Results and discussion}

We discovered the values of the influence, popularity and inclination index of intact and integrated pupils within the frame of each class (6. A, 6. B, 7. A) at the beginning, before applying the experimental factor (experiential learning with physical movement activities). It was confirmed that pupils with behavioural disorders, due to their handicaps and subsequent integration, had lower social positions in class than intact pupils.

We observed a statistically significant difference in assessing of intact and integrated pupils comparing influence, popularity and inclination index in class 6 . A before the experiment (Table 2).

Tables 2

Influence, popularity and inclination index of intact and integrated pupils of class 6. A before the experiment

\begin{tabular}{|c|c|c|c|c|c|c|c|c|}
\hline $\begin{array}{l}\text { INFLUENCE } \\
\text { Intact pupils }\end{array}$ & $\begin{array}{l}\text { Integrated } \\
\text { pupils }\end{array}$ & \multicolumn{2}{|c|}{$\begin{array}{l}\text { POPULARITY } \\
\text { Intact pupils }\end{array}$} & $\begin{array}{l}\text { Integrated } \\
\text { Pupils }\end{array}$ & $\begin{array}{l}\text { INCLINATION } \\
\text { Intact pupils }\end{array}$ & $\begin{array}{l}\text { Integrated } \\
\text { pupils }\end{array}$ \\
\hline $\mathrm{N}$ & 13 & 5 & $\mathrm{~N}$ & 13 & 5 & $\mathrm{~N}$ & 13 & 5 \\
\hline $\mathrm{AA}$ & 1.868 & 2.624 & $\mathrm{AA}$ & 1.914 & 2.764 & $\mathrm{AA}$ & 1.959 & 2.729 \\
\hline $\mathrm{SD}$ & 0.138 & 0.089 & $\mathrm{SD}$ & 0.212 & 0.231 & $\mathrm{SD}$ & 0.208 & 0.169 \\
\hline $\mathrm{t}$ & \multicolumn{2}{|c|}{$10.53^{* * *}$} & $\mathrm{t}$ & \multicolumn{2}{|c|}{$6.387^{* * *}$} & $\mathrm{t}$ & \multicolumn{2}{c|}{$6.610^{* * *}$} \\
\hline $\mathrm{p}$ & $4.902 * \mathrm{E}-08 \mathbf{p}<\mathbf{0 . 0 1}$ & $\mathrm{p}$ & \multicolumn{2}{|c|}{$1.6914^{*} \mathrm{E}-05 \mathbf{p}<\mathbf{0 . 0 1}$} & $\mathrm{p}$ & $1.1696 * \mathrm{E}-05 \mathbf{p}<\mathbf{0 . 0 1}$ \\
\hline
\end{tabular}

Notes for all tables $2-19$

$N$ - number of pupils, AA - arithmetical average, $S D$ - standard deviation, $t$-testing criteria for independent selections, $p$-statistical significance.

Certain changes came up after the realization of experiential learning. The value of influence index in class 6 . A changed only slightly in improvement of integrated pupils influence in the class.

We assume that in the case of long-term influence of an experimental factor, the values of differences between intact and integrated pupils could lose statistical significance (Table 3).

Table 3

Influence, popularity and inclination index of intact and integrated pupils of class 6. A after the experiment

\begin{tabular}{|c|c|c|c|c|c|c|c|c|}
\hline $\begin{array}{l}\text { INFLUENCE } \\
\text { Intact pupils }\end{array}$ & $\begin{array}{l}\text { Integrated } \\
\text { pupils }\end{array}$ & \multicolumn{2}{l|}{$\begin{array}{l}\text { POPULARITY } \\
\text { Intact pupils }\end{array}$} & $\begin{array}{l}\text { Integrated } \\
\text { Pupils }\end{array}$ & $\begin{array}{l}\text { INCLINATION } \\
\text { Intact pupils }\end{array}$ & $\begin{array}{l}\text { Integrated } \\
\text { pupils }\end{array}$ \\
\hline $\mathrm{N}$ & 13 & 5 & $\mathrm{~N}$ & 13 & 5 & $\mathrm{~N}$ & 13 & 5 \\
\hline $\mathrm{AA}$ & 2.00 & 2.329 & $\mathrm{AA}$ & 1.927 & 2.152 & $\mathrm{AA}$ & 1.995 & 2.117 \\
\hline $\mathrm{SD}$ & 0.168 & 0.197 & $\mathrm{SD}$ & 0.217 & 0.158 & $\mathrm{SD}$ & 0.219 & 0.149 \\
\hline $\mathrm{t}$ & \multicolumn{2}{|c|}{$3.802 * *$} & $\mathrm{t}$ & \multicolumn{2}{|c|}{1.852} & $\mathrm{t}$ & \multicolumn{2}{|c|}{1,537} \\
\hline $\mathrm{p}$ & $\mathrm{p}=0.00194$ & $\mathbf{p}<\mathbf{0 . 0 1}$ & $\mathrm{p}$ & $\mathrm{p}=0.0853 \mathbf{N}$ & $\mathrm{p}$ & $\mathrm{p}=0.1466 \mathbf{N}$ \\
\hline
\end{tabular}


A significant shift towards the advantage of integrated pupils was discovered in the popularity and inclination index, as differences in values between intact and integrated pupils shifted outside the level of statistical significance. Madden and Slavin (1983) also concluded from efficacy studies that students with mild disabilities would most benefit from placement in general education classrooms. Fuchs et al. (2002) indicated that students enjoyed the same social standing as most nondisabled classmates.

Table 4

Influence. popularity and inclination index of intact and integrated pupils of class 6. B before the experiment

\begin{tabular}{|c|c|c|c|c|c|c|c|c|}
\hline $\begin{array}{l}\text { INFLUENCE } \\
\text { Intact pupils }\end{array}$ & $\begin{array}{l}\text { Integrated } \\
\text { pupils }\end{array}$ & \multicolumn{2}{|l|}{$\begin{array}{l}\text { POPULARITY } \\
\text { Intact pupils }\end{array}$} & $\begin{array}{l}\text { Integrated } \\
\text { Pupils }\end{array}$ & $\begin{array}{l}\text { INCLINATION } \\
\text { Intact pupils }\end{array}$ & $\begin{array}{l}\text { Integrated } \\
\text { pupils }\end{array}$ \\
\hline $\mathrm{N}$ & 13 & 6 & $\mathrm{~N}$ & 13 & 6 & $\mathrm{~N}$ & 13 & 6 \\
\hline $\mathrm{AA}$ & 1.846 & 2.824 & $\mathrm{AA}$ & 1.752 & 2.731 & $\mathrm{AA}$ & 1.790 & 2.759 \\
\hline $\mathrm{SD}$ & 0.172 & 0.212 & $\mathrm{SD}$ & 0.208 & 0.249 & $\mathrm{SD}$ & 0.1714 & 0.218 \\
\hline $\mathrm{t}$ & \multicolumn{2}{|c|}{$9.437^{* * *}$} & $\mathrm{t}$ & \multicolumn{2}{|c|}{$7.685^{* * *}$} & $\mathrm{t}$ & $9.195^{* * *}$ \\
\hline $\mathrm{p}$ & $1.065^{*} \mathrm{E}-07$ & $\mathbf{p}<\mathbf{0 . 0 1}$ & $\mathrm{p}$ & $1.407 * \mathrm{E}-06 \quad \mathbf{p}<\mathbf{0 . 0 1}$ & $\mathrm{p}$ & $1.555^{*} \mathrm{E}-07 \quad \mathbf{p}<\mathbf{0 . 0 1}$ \\
\hline
\end{tabular}

We got these results during preparatory diagnostics in class 6. B (Table 4). As expected, even statistically highly significance difference appeared in influence, popularity and inclination index in the assessment of intact and integrated pupils from the view of the whole class.

Table 5

Influence, popularity and inclination index of intact and integrated pupils of class 6. B after the experiment

\begin{tabular}{|c|c|c|c|c|c|c|c|c|}
\hline $\begin{array}{l}\text { INFLUENCE } \\
\text { Intact pupils }\end{array}$ & $\begin{array}{l}\text { Integrated } \\
\text { pupils }\end{array}$ & \multicolumn{2}{l|}{$\begin{array}{l}\text { POPULARITY } \\
\text { Intact pupils }\end{array}$} & $\begin{array}{l}\text { Integrated } \\
\text { Pupils }\end{array}$ & $\begin{array}{l}\text { INCLINATION } \\
\text { Intact pupils }\end{array}$ & $\begin{array}{l}\text { Integrated } \\
\text { pupils }\end{array}$ \\
\hline $\mathrm{N}$ & 13 & 6 & $\mathrm{~N}$ & 13 & 6 & $\mathrm{~N}$ & 13 & 6 \\
\hline $\mathrm{AA}$ & 1.876 & 1.944 & $\mathrm{AA}$ & 1.752 & 1.888 & $\mathrm{AA}$ & 1,807 & 2,019 \\
\hline $\mathrm{SD}$ & 0.172 & 0.192 & $\mathrm{SD}$ & 0.208 & 0.195 & $\mathrm{SD}$ & 0,169 & 0,206 \\
\hline $\mathrm{t}$ & \multicolumn{2}{|c|}{0.3131} & $\mathrm{t}$ & \multicolumn{2}{|c|}{0.9758} & $\mathrm{t}$ & 1.890 \\
\hline $\mathrm{p}$ & $\mathrm{p}=0.7585 \mathbf{N}$ & $\mathrm{p}$ & $\mathrm{p}=0.3446 \mathbf{N}$ & $\mathrm{p}$ & $\mathrm{p}=0.07795 \mathbf{N}$ \\
\hline
\end{tabular}

These changes happened in the class 6 . B after the realization of the movement programme (Table 5). The influence index showed a notable shift benefiting the integrated pupils, since the average values' differences between intact and integrated pupils shifted out of the level of statistical significance. No significant relationship between the perception of social positions of intact and integrated pupils from the view of the whole class has been discovered. The values of the popularity and inclination index have not been significant on any of the statistically significance level either. We can state that the interpersonal relationships in class 6 . B shifted towards the anticipated level. 
The results of class 7. A before the experiment showed that the influence index gained a statistically significant difference in the assessment of intact and integrated pupils obtained from classmates. The popularity and inclination index showed a statistically significant difference between the average values of intact and integrated pupils in class (Table 6).

Table 6

Influence, popularity and inclination index of intact and integrated pupils of class 7. A before the experiment

\begin{tabular}{|c|c|c|c|c|c|c|c|c|}
\hline \multicolumn{2}{|c|}{$\begin{array}{l}\text { INFLUENCE } \\
\text { Intact pupils }\end{array}$} & \multirow{2}{*}{$\begin{array}{l}\begin{array}{l}\text { Integrated } \\
\text { pupils }\end{array} \\
4\end{array}$} & \multicolumn{2}{|c|}{$\begin{array}{l}\text { POPULARITY } \\
\text { Intact pupils }\end{array}$} & \multirow{2}{*}{$\begin{array}{l}\begin{array}{l}\text { Integrated } \\
\text { Pupils }\end{array} \\
4\end{array}$} & \multicolumn{2}{|c|}{$\begin{array}{l}\text { INCLINATION } \\
\text { Intact pupils }\end{array}$} & \multirow{2}{*}{$\begin{array}{l}\begin{array}{l}\text { Integrated } \\
\text { pupils }\end{array} \\
4\end{array}$} \\
\hline $\mathrm{N}$ & 13 & & $\mathrm{~N}$ & 13 & & $\mathrm{~N}$ & 13 & \\
\hline $\mathrm{AA}$ & 1.851 & 2.422 & AA & 1.813 & 2.500 & AA & 1.754 & 2.515 \\
\hline SD & 0.123 & 0.031 & SD & 0.200 & 0.0884 & SD & 0.168 & 0.128 \\
\hline $\mathrm{t}$ & \multicolumn{2}{|c|}{$8.947 * * *$} & $\mathrm{t}$ & \multicolumn{2}{|c|}{$6.535 * * *$} & $\mathrm{t}$ & \multicolumn{2}{|c|}{$8.259 * * *$} \\
\hline $\mathrm{p}$ & \multicolumn{2}{|c|}{$\mathrm{p}=2.12 * E-07 \mathbf{p}<\mathbf{0 . 0 1}$} & $p$ & \multicolumn{2}{|c|}{$9.44 * \mathrm{E}-06 \quad \mathbf{p}<\mathbf{0 . 0 1}$} & $\mathrm{p}$ & \multicolumn{2}{|c|}{$5.8 * \mathrm{E}-07 \quad \mathbf{p}<\mathbf{0 . 0 1}$} \\
\hline
\end{tabular}

We obtained following results after the experiment in class 7. A. The influence index showed a positive change in behalf of the integrated pupils in class. Differences in values moved beyond the statistical significance level. Therefore, no significant relationship perceiving social positions of intact and integrated pupils in class has been found. Popularity index values showed only subtle changes, because the statistical significance level remained on a significant level. We assume that in a case of long-term influence, the difference values would get outside of the statistical significance level. The inclination index showed a statistically important difference in the perception of social positions of intact and integrated pupils in the whole 7. A class (Table 7).

Table 7

Influence, popularity and inclination index of intact and integrated pupils of class 7. A after the experiment

\begin{tabular}{|c|c|c|c|c|c|c|c|c|}
\hline $\begin{array}{l}\text { INFLUENCE } \\
\text { Intact pupils }\end{array}$ & $\begin{array}{l}\text { Integrated } \\
\text { pupils }\end{array}$ & \multicolumn{2}{|l|}{$\begin{array}{l}\text { POPULARITY } \\
\text { Intact pupils }\end{array}$} & $\begin{array}{l}\text { Integrated } \\
\text { Pupils }\end{array}$ & $\begin{array}{l}\text { INCLINATION } \\
\text { Intact pupils }\end{array}$ & $\begin{array}{l}\text { Integrated } \\
\text { pupils }\end{array}$ \\
\hline $\mathrm{N}$ & 13 & 4 & $\mathrm{~N}$ & 13 & 4 & $\mathrm{~N}$ & 13 & 4 \\
\hline $\mathrm{AA}$ & 1.879 & 2.046 & $\mathrm{AA}$ & 1.783 & 2.078 & $\mathrm{AA}$ & 1,693 & 1,891 \\
\hline $\mathrm{SD}$ & 0.147 & 0.164 & $\mathrm{SD}$ & 0.208 & 0.281 & $\mathrm{SD}$ & 0,118 & 0,078 \\
\hline $\mathrm{t}$ & \multicolumn{2}{|c|}{1.934} & $\mathrm{t}$ & \multicolumn{2}{|c|}{$2.291^{*}$} & $\mathrm{t}$ & $3.113^{* *}$ \\
\hline $\mathrm{p}$ & $\mathrm{p}=0.0722 \mathbf{N}$ & $\mathrm{p}$ & $\mathrm{p}=0,0368 \mathbf{p}<\mathbf{0 . 0 5}$ & $\mathrm{p}$ & $\mathrm{p}=0.0072 \quad \mathbf{p}<\mathbf{0 . 0 1}$ \\
\hline
\end{tabular}

Average value differences in influence, popularity and inclination indexes obtained from intact and integrated pupils of every observed class are graphically represented in figure 1 before the experiment and, for the need of comparison, after the experimental application of the experiential education programme as well. 


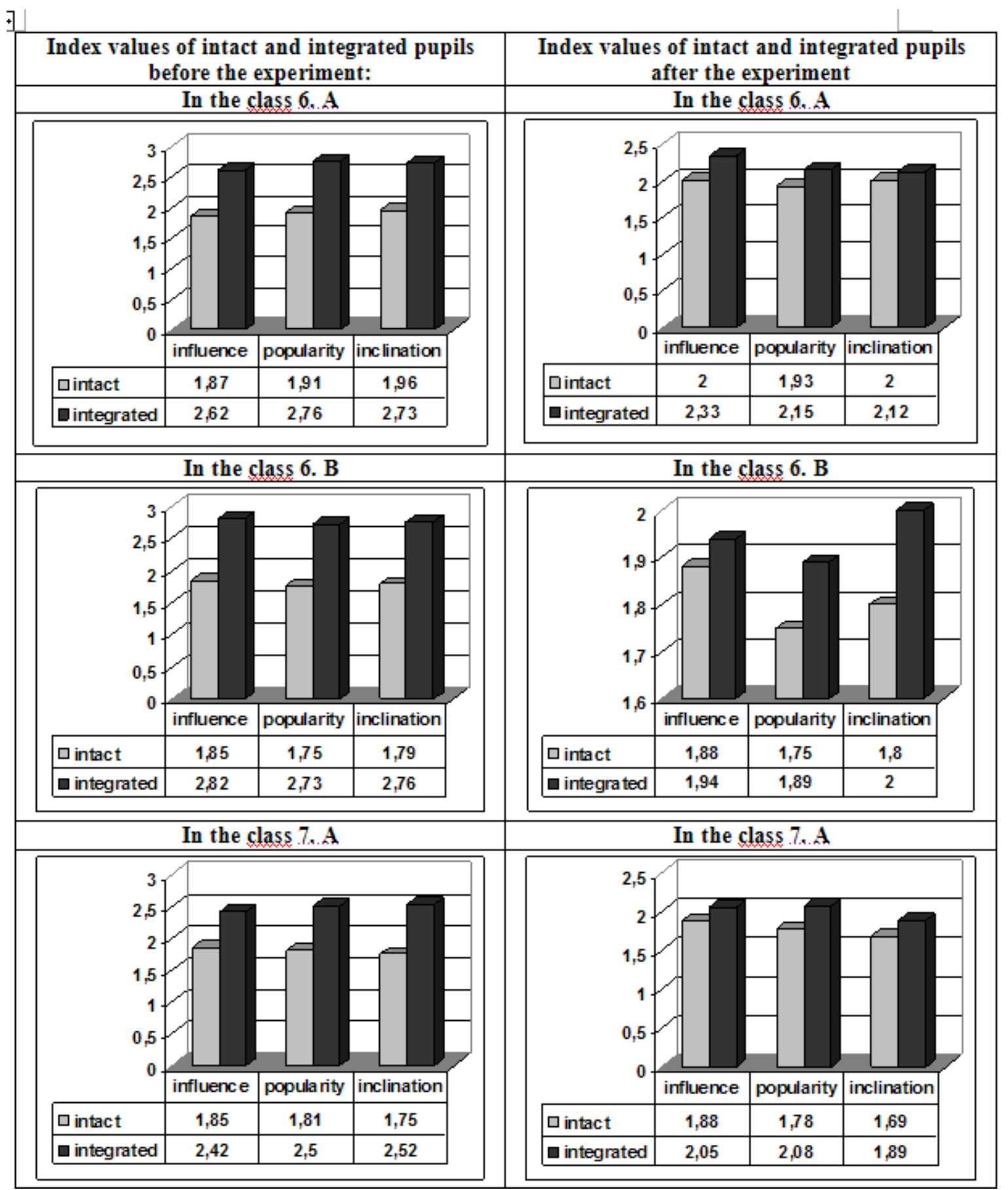

Figure 1

Index values of intact and integrated pupils before and after the experiment in selected classes

\section{Conclusion}

The aim of the work was to broaden the knowledge of experiential learning connected to the pupils' physical movement activity as an inseparable part of the educational process and to verify its influence on the changes of level and quality in the field of social relations in selected integrated classes with pupils suffering from behavioural disorders. 
The outcome was that after integrating the experiential programme of physical movement activities into the process of learning, the social positions of the pupils in selected classes (6. A, 6. B and 7. A) changed in a positive way, mainly the positions of pupils with behavioural disorders. These pupils advanced in the field of influence, popularity and inclination from average values obtained from all their classmates to values, where the difference between intact and integrated pupils is not on the level of statistical significance anymore.

Experiential learning should be part of every educational process at schools. It is particularly adequate in fields where developing everyone's own personality and selfknowledge, influencing the attitude of people, team cohesiveness, knowledge of team roles, uncovering strong and weak points of teamwork and leadership are important aspects. Experiential learning also has its value where the society (or an individual) needs to find out its own progress possibilities and creativity development. It helps to develop strategic planning skills, tactical thinking. It teaches individuals to bear defeat, to respect opponents, etc. It is the teacher's call, which of the many didactic methods and mediums he will choose for his teaching, which components he will use for creating an experience for his pupils, where he will apply all accessible knowledge and information and if he will use the most suitable organizational forms of teaching to achieve the desired positive results.

A moving classroom is a happy classroom (Van 2012).

\section{References}

1. ČAPEK, R., 2010. Tř́dní klima a školní klima. Praha: Grada Publishing. ISBN 978-80247-2742-4.

2. FUCHS, D., L.S. FUCHS, P.G. MATHES and E.A. MARTINEZ, 2002. Preliminary Evidence on the Social Standing of Students with Learning Disabilities in PALS and No-PALS Classrooms. Learning Disabilities Research\&Practice. 17(4), 205-215.

3. GAJDOŠOVÁ, E., 2000. Poznávanie sociálnych vzt’ahov v triede. Práca so sociometricko-ratingovým dotazníkom. Bratislava: Metodické centrum mesta Bratislava. ISBN 80-7164-268-1.

4. GAVORA, P., 2010. Akí sú moji žiaci: Pedagogická diagnostika žiaka. 2. vyd. Nitra: Enigma Publishing s.r.o. ISBN 978-80-89132-91-1. 
5. HANUŠ, R. a L. CHYTILOVÁ, 2009. Zážitkové pedagogické učení: modely zkušenostniho učení, motivace, prostředky zážitkové pedagogiky, projektování. Praha: Grada Publishing. ISBN 978-80-247-2816-2.

6. JANSKÝ, P., 2004. Problémové ditě a náhradní výchovná péče ve školských zařizeních. Hradec Králové: Gaudeamus. ISBN 80-7041-114-7.

7. KASÍKOVÁ, H., 2010. Kooperatívni učení, kooperatívni škola. 2. rozšir. a aktualiz. vyd. Praha: Portal. ISBN 978-80-7367-712-1-3.

8. MADDEN, N.A., and R.E. SLAVIN, 1983. Mainstreaming Students With Mild Academic Handicaps: Academic and Social Outcomes. Review of Educational Research. 84, 131-138.

9. MARTÍNEK, Z., 2009. Agresivita a kriminalita školni mládeže. Praha: Grada Publishing. ISBN 978-80-247-2310-5.

10. ORAVCOVÁ, J., 2004. Sociálna psychológia. Banská Bystrica: FHV UMB. ISBN 808055-980-5.

11. PÁNISOVÁ, M. a J. PERÁČKOVÁ, 2012. Kooperatívne hry a cvičenia. In: Telesná výchova \& šport. 22(1), V-VIII - metodická príloha. ISSN 1335-2245.

12. PELÁNEK, R., 2008. Př́ručka inštruktora zážitkových akcí. Praha: Portál, s.r.o. ISBN 878-80-7367-353-6.

13. PERÁČKOVÁ, J., 2014. Zážitkové vyučovanie telesnej a športovej výchovy. In: ANTALA, B. a kol. Telesná a športová výchova a súčasná škola, s. 104-111. ISBN 978-80-971466-1-0.

14. PERÁČKOVÁ, J., 2000. Problémoví žiaci a problémy žiakov v telesnej výchove. In: Acta Facultatis Educationis physicae Universitatis Comenianae, 41. Bratislava: Univerzita Komenského, s. 131-146. ISBN 80-223-1567-2.

15. PETLÁK, E., 2006. Klíma školy a klíma triedy. Bratislava: IRIS. ISBN 80-89018-971.

16. ŠIRCOVÁ, I., 2007. S det'mi v prírode: zážitková výchova po celý rok. Praha: Portál, s.r.o. ISBN 978-80-7367-201-0.

17. ŠKODA, J. a S. FISCHER, 2008. Speciální pedagogika. Edukace a rozvoj osob se somatickým, psychickým a znevýhodnením. Praha: Triton. ISBN 80-7387-014-2.

18. VÁGNEROVÁ, M., 2002. Úvod do psychologie. Praha: Univerzita Karlova. ISBN 80246-0015-3.

19. VÁGNEROVÁ, M., 2005. Školni poradenská psychologie pro pedagogy. Praha: Karolínum. ISBN 80-246-1074-4. 
20. VAN, M., 2012. Movement in Learning: Revitalizing the Classroom. Washington DC: MA TESOL Collection. Paper 541.

21. VEREŠOVÁ, J., 2014. Zážitková pedagogika vo vol’nočasových aktivitách. Bratislava: Metodicko-pedagogické centrum v Bratislave. ISBN 978-80-8052-581-1.

22. VYKOPALOVÁ, H., 1992. Sociální klima školní třídy a možnosti jeho ovlivňování. Olomouc: Univerzita Palackého v Olomouci. ISBN 80-7067-161-0. 